\title{
At-Taqaddum
}

Vol. 11 No. 2 (2019) pp 234-255

DOI: http://dx.doi.org/10.21580/at.v1li2.4632

\section{PATH ANALYSIS PENGARUH KUALITAS PRODUK, KUALITAS PELAYANAN, KEPUASAN PELANGGAN TERHADAP LOYALITAS PELANGGAN PEGADAIAN SYARIAH KUSUMANEGARA YOGYAKARTA}

\author{
Singgih Muheramtohadi \\ Fakultas Ekonomi dan Bisnis Islam UIN Walisongo Semarang \\ Email: singgih_muheramtohadi@walisongo.ac.id
}

\begin{abstract}
Financial institutions play an important role in the life of a country that functions: 1) raising funds; 2) channeling community funds effectively and efficiently. Islamic financial institutions can be an alternative as a means of borrowing capital or investing funds. Sharia pawnshop is part of Islamic financial institutions which have an important role in national economic security. A sharia financial institution including sharia pawnshop must be able to carry out a marketing strategy. Among the things to consider are customer loyalty. Among the several factors that influence customer loyalty are product quality, service quality and customer satisfaction.

The objectives to be achieved in this research are to find out: 1) the influence of product quality on customer loyalty in Kusumanegara Yogyakarta sharia pawnshop; 2) the effect of service quality on customer loyalty sharia pawnshop; Kusumanegara Yogyakarta; 3) the effect of customer satisfaction on customer loyalty shariah pawshop Kusumanegara Yogyakarta; and 4) the influence of products, service quality, and customer satisfaction simultaneously on customer loyalty sharia panshop Kusumanegara Yogyakarta.

This type of research used in this research is quantitative research using Path Analysis. This sample was chosen using Random Sampling, namely by randomly selecting a sample from the population. There are 176 respondents. Data collection techniques in this study used a questionnaire.
\end{abstract}


The test results indicate the results that support the hypothesis $(R=0.35)$ then show that hypothesis 1 is accepted at a significant level $a=0.001$ but this relationship is relatively small. These results indicate that product quality is a variable that is considered less important in forming services. The test results indicate the results that support the hypothesis $(\mathrm{R}=0.43)$, then show that hypothesis 2 is accepted at the significance level $a=0.01$. This shows that product quality is a variable that is considered significant in shaping customer satisfaction. The test results indicate the results that support the bypothesis $(\mathrm{R}=0.28)$, then show that hypothesis 3 is accepted at the significance level $a=0.05$. These results indicate that the quality of goods is a variable that is considered not very essential in forming customer loyalty. The test results indicate the results that support the hypothesis $(\mathrm{R}=0.48)$, then show that bypothesis 4 is accepted at the significance level $a=0.05$. These results indicate that service is a variable that is considered important in shaping customer satisfaction. The test results indicate the results that support the hypothesis $(\mathrm{R}=0.32)$, then show that bypothesis 5 is accepted at the significance level $a=0.05$. These results indicate that service is a variable that is considered not very important in forming customer loyalty. The test results indicate the results that support the bypothesis $(R=0.65)$, then show that hypothesis $\sigma$ is accepted at the significance level $a=0.001$. These results indicate that customer satisfaction is a variable that is considered very important in forming customer loyalty.

Keywords: Path Analysis, Product Quality, Service, Customer Satisfaction, Customer Loyalty

\begin{abstract}
Abstrak
Lembaga keuangan berperan penting penting dalam kehidupan suatu negara yang berfungsi: 1) menghimpun dana; 2) menyalurkan dana masyarakat secara efektif dan efisien. Lembaga keuangan syari'ah bisa menjadi alternatif sebagai sarana peminjaman modal atau menginvestasikan dana. Pegadaian Syariah merupakan bagian dari Lembaga keuangan syari'ah yang mempunyai peran penting pada ketahanan ekonomi nasional. Suatu Lembaga keuangan syari'ah termasuk juga pegadaian syariah haruslah mampu melakukan strategi pemasaran. Diantara hal-hal yang perlu dipertimbangkan adalah loyalitas pelanggan.
\end{abstract}




\section{At-Taqaddum}

Vol. 11 No. 2 (2019) pp 234-255

DOI: http://dx.doi.org/10.21580/at.v11i2.4632

Di antara beberapa faktor yang mempengaruhi loyalitas pelanggan yaitu kualitas produk, kualitas layanan dan kepuasan pelanggan.

Tujuan yang ingin dicapai dalam penelitian adalah untuk mengetahui: 1) pengaruh kualitas produk terhadap loyalitas pelanggan Pegadaian syariah Kusumanegara Yogyakarta; 2) pengaruh kualitas pelayanan terhadap loyalitas pelanggan Pegadaian syariah Kusumanegara Yogyakarta; 3) pengaruh kepuasan pelanggan terhadap loyalitas pelanggan Pegadaian syariah Kusumanegara Yogyakarta; dan 4) pengaruh produk, kualitas pelayanan, dan kepuasan pelanggan secara serentak terhadap loyalitas pelanggan Pegadaian syariah Kusumanegara Yogyakarta.

Jenis penelitian yang digunakan dalam penelitian ini adalah penelitian kuantitatif dengan menggunakan Analisis Jalur. Sampel ini dipilih dengan menggunakan Random Sampling yaitu dengan memilih secara acak sampel dari populasi. Terdapat 176 responden. Teknik pengumpulan data dalam penelitian ini menggunakan angket.

Hasil pengujian mengindikasikan hasil yang mendukung hipotesis $(\mathrm{R}=0.35)$ maka menunjukkan bahwa hipotesis 1 diterima pada tingkat signifikan $\alpha=0,001$ akan tetapi hubungan ini relatif kecil. Hasil ini menunjukkan bahwa Kualitas Produk merupakan variabel yang dianggap kurang penting dalam membentuk Pelayanan. Hasil pengujian mengindikasikan hasil yang mendukung hipotesis $(\mathrm{R}=0.43)$, maka menunjukkan bahwa hipotesis 2 diterima pada tingkat signifikansi $\alpha=$ 0,01 . Hal ini menunjukkan bahwa kualitas produk merupakan variabel yang dianggap signifikan dalam membentuk kepuasan pelanggan. Hasil pengujian mengindikasikan hasil yang mendukung hipotesis $(\mathrm{R}=0.28)$, maka menunjukkan bahwa hipotesis 3 diterima pada tingkat signifikansi $\alpha$ $=0,05$. Hasil ini menunjukkan bahwa kualitas barang merupakan variabel yang dianggap tidak terlalu esensial dalam membentuk loyalitas pelanggan. Hasil pengujian mengindikasikan hasil yang mendukung hipotesis $(\mathrm{R}=0.48)$, maka menunjukkan bahwa hipotesis 4 diterima pada tingkat signifikansi $\alpha=0,05$. Hasil ini menunjukkan bahwa pelayanan merupakan variabel yang dianggap penting dalam membentuk kepuasan 
pelanggan. Hasil pengujian mengindikasikan hasil yang mendukung hipotesis $(\mathrm{R}=0.32)$, maka menunjukkan bahwa hipotesis 5 diterima pada tingkat signifikansi $\alpha=0,05$. Hasil ini menunjukkan bahwa pelayanan merupakan variabel yang dianggap tidak terlalu penting dalam membentuk loyalitas pelanggan. Hasil pengujian mengindikasikan hasil yang mendukung hipotesis $(\mathrm{R}=0.65)$, maka menunjukkan bahwa hipotesis 6 diterima pada tingkat signifikansi $\alpha=0,001$. Hasil ini menunjukkan bahwa kepuasan pelanggan merupakan variabel yang dianggap sangat penting dalam membentuk loyalitas pelanggan.

Kata kunci: Path Analysis, Kualitas Produk, Layanan, Kepuasan Pelanggan, Loyalitas Pelanggan.

\section{Pendahuluan}

Lembaga keuangan berperan penting penting dalam kehidupan suatu negara yang berfungsi: 1) menghimpun dana; 2) menyalurkan dana masyarakat secara efektif dan efisien. Lembaga keuangan syari'ah bisa menjadi alternatif sebagai sarana peminjaman modal atau menginvestasikan dana. ${ }^{1}$ Muhammad memaparkan "lembaga keuangan syari'ah mempunyai peran peran penting sebagai lembaga ekonomi berbasis syari'ah dengan prinsip-prinsip muamalah dalam bentuk ekonomi islam." "2 Pegadaian Syariah merupakan bagian dari Lembaga keuangan syariah yang mempunyai peran penting pada ketahanan ekonomi nasional. ${ }^{3}$ Suatu Lembaga keuangan syari'ah termasuk juga pegadaian syari'ah haruslah mampu melakukan strategi pemasaran. Di antara hal-hal yang perlu dipertimbangkan adalah loyalitas pelanggan. Di

\footnotetext{
${ }^{1}$ Heri Sudarsono, Bank dan Lembaga Kenangan Syariah, Cet. III, (Yogyakarta: Ekonomi, 2005), pp. 27

2 Muhamad (ed.), Bank Syariah Analisis Kekuatan, Peluang, Kelemabandan Ancaman, (Yogyakarta: Ekonisa, 2006), pp. 135.

${ }^{3}$ Hendi Sunendi, BMT dan Bank Islam, (Bandung: Pustaka Bani Quraisy, 2004), pp.5
} 


\section{At-Taqaddum}

Vol. 11 No. 2 (2019) pp 234-255

DOI: http://dx.doi.org/10.21580/at.v11i2.4632

antara beberapa faktor yang mempengaruhi loyalitas pelanggan yaitu kualitas produk, kualitas layanan dan kepuasan pelanggan. ${ }^{4}$

Lupiyoadi menjelaskan "dengan adanya persaingan antara perusahaan yang bergerak dalam bidang sejenis, dalam banyak hal sebenarnya akan menimbulkan dampak positif bagi perusahaanperusahaan tersebut. Dampak positif tersebut antara lain, perusahaan akan berlomba-lomba memberikan pelayanan dengan kualitas yang terbaik kepada konsumen sehingga konsumen dapat merasakan kepuasan setelah menggunakan jasa layanan perusahaan tersebut. Pelayanan yang berkualitas dan bermutu merupakan salah satu kunci keberhasilan untuk memuaskan pelanggan dalam berbagai usaha yang bersifat jasa." ${ }^{5}$

Menurut Schnaars dalam Tjiptono menjelaskan "pada dasarnya tujuan dari suatu bisnis adalah untuk menciptakan para konsumen yang merasa puas. Kepuasan konsumen merupakan hasil dari perbandingan antara harapan dan kenyataan yang diterima oleh pelanggan dalam mengkonsumsi barang dan jasa." 6 Tjiptono memaparkan bahwa "terdapat dua kemungkinan untuk harapan yang terbentuk karena informasi dari penjual. Kemungkinan yang pertama adalah penjual menawarkan informasi yang berlebihan kepada pelanggan tentang suatu produk yang dijual, maka pelanggan akan mempunyai pengharapan yang terlalu tinggi, sehingga berakibat ketidakpuasan apabila penjual tidak dapat memenuhi janji sesuai dengan informasi yang diberikan. Kemungkinan kedua adalah apabila penjual kurang memberikan informasi kepada pelanggan, maka tingkat pengharapan pelanggan menjadi rendah terhadap suatu produk sehingga transaksi jual beli tidak akan terjadi. Kepuasan yang tinggi atau kesenangan yang meningkat cenderung berdampak langsung pada tingkah laku dan sikap pelanggan dengan menurunnya tingkat keluhan, penambahan kepercayaan dan pengulangan pembelian jasa juga terjadinya

4Philip Kotler dan Kevin Lance Keller, Manajemen Pemasaran. Jilid 1 dan 2 edisi 12. (Jakarta: PT. indeks, 2007), pp.344

${ }^{5}$ Rambat Lupiyoadi, Manajemen Pemasaran Jasa, Teori dan Praktek, Edisi Pertama, (Jakarta: Salemba Empat, 2001), pp. 45

${ }^{6}$ Fandy Tjiptono, Strategi Pemasaran Edisi ketiga, (Yogyakarta: Andi, 2008) 
kelekatan emosional terhadap merek, dan juga preferensi rasional sehingga hasilnya adalah kesetiaan (loyalitas) pelanggan yang tinggi. Selain itu terciptanya loyalitas pelanggan dapat juga membentuk suatu rekomendasi dan mulut ke mulut (word of mouth) yang menguntungkan bagi perusahaan."

Di era yang penuh dengan persaingan seperti sekarang, cukuplah sulit untuk memenangkan persaingan, oleh karena itu, lokasi merupakan hal yang penting selain mengandalkan kualitas produk dan membuat konsumen untuk senantiasa puas. Yang berdampak pada loyalitas konsumen. Basu Swashta ${ }^{8}$ mengemukakan bahwa "lokasi (place) menunjukkan berbagai kegiatan yang dilakukan perusahaan untuk menjadikan produknya dapat diperoleh dan tersedia bagi konsumen." Maka, Krajewski menambahkan bahwa "lokasi suatu bisnis mempunyai efek signifikan terhadap biaya operasi perusahaan, harga produk atau jasa dan mempengaruhi daya saing perusahaan."

Sementara itu, banyak para ahli berpendapat bahwa bahwa "kinerja perusahaan ditentukan oleh tingkat loyalitas pelanggan dimana loyalitas pelanggan dipengaruhi oleh (driven) kepuasan pelanggan." 10 Oleh karena itu kartajaya mengungkapkan bahwa "dapat ditarik proposisi yaitu: rendahnya kinerja perusahaan dapat dijadikan indikasi loyalitas yang rendah." 11 Ada fenomena yang menarik untuk di amati, yaitu meskipun hasil dari penjualan menurun iklim perdangan amatlah baik karena sebuah usaha mampu menjaga loyalitas pelanggan bahkan cenderung meningkat.

"Iklim kompetisi dalam lembaga keungan syari'ah semakin terasa. Di sisi lain perubahan lingkungan yang demikian pesat semakin

${ }^{7}$ Fandy Tjiptono, Strategi Pemasaran Edisi ketiga, (Yogyakarta: Andi, 2008)

${ }^{8}$ Basu Swastha dan Hani Handoko, Manajemen Pemasaran, Analisa Perilaku Konsumen, (Yogyakarta: BPFE, 2000)

${ }^{9}$ Lee. J Krajewski \& Larry P. Ritzman, Operations Management: Strategy and Analysis, Fourth Edition, (Addison Wesly Publishing Co., 1996)

${ }^{10}$ Mark A. Fryman, Quality and Process Improvement, (Delmar Thomson Learning, 2002)

${ }^{11}$ Hermawan Kartajaya, Strategic Marketing Plan, Jakarta: PT. Gramedia. Pustaka Utama, 2004) 


\section{At-Taqaddum}

Vol. 11 No. 2 (2019) pp 234-255

DOI: http://dx.doi.org/10.21580/at.v11i2.4632

mendukung kompetisi yang sedang terjadi saat ini. Menurut Dick dan $\mathrm{Basu}^{12}$, salah satu tujuan utama aktivitas pemasaran seringkali dilihat dari pencapaian loyalitas pelanggan melalui strategi pemasaran."13 Menurut Caruana "loyalitas pelanggan merupakan bagian terpenting pada pengulangan pembelian pada pelanggan." 14

Tujuan yang ingin dicapai dalam penelitian adalah untuk mengetahui: 1) pengaruh kualitas produk terhadap loyalitas pelanggan Pegadaian syariah Kusumanegara Yogyakarta; 2) pengaruh kualitas pelayanan terhadap loyalitas pelanggan Pegadaian syariah Kusumanegara Yogyakarta; 3) pengaruh kepuasan pelanggan terhadap loyalitas pelanggan Pegadaian syariah Kusumanegara Yogyakarta; dan 4) pengaruh produk, kualitas pelayanan, dan kepuasan pelanggan secara serentak terhadap loyalitas pelanggan Pegadaian syariah Kusumanegara Yogyakarta.

\section{Kajian Teori}

\section{Pegadaian Syariah}

Al-Habsu, artinya penahanan." ${ }^{15}$ Dia menjelaskan lagi bahwa "sedangkan menurut syara' artinya akad yang objeknya menahan harga terhadap sesuatu hak yang mungkin diperoleh bayaran yang sempurna darinya." Dalam definisinya "rahn adalah barang yang digadaikan, rabin adalah orang mengadaikan, sedangkan murtabin adalah orang yang memberikan pinjaman.”

Adapun pengertian rahn menurut Imam Abu Zakaria Al-Anshary, dalam kitabnya Fathul Wahab, mendefinisikan "rahn adalah menjadikan benda

\footnotetext{
${ }^{12}$ Dick, A.S dan Basu, K., 1994, "Customer Loyalty: Toward an Integrated Conceptual Framework", Journal of The Academy Marketing Science, Vol.22, pp.99-113.

${ }^{13}$ Siregar, S.P. 2004. Analisis Kepuasan Para Anggota Terbadap Program Loyalitas Astraworld. Tesis Fakultas Ekonomi Universitas Indonesia, tidak diterbitkan.

${ }^{14}$ Caruana, A. 2002. Service Loyalty The Effects of Service Quality and The Mediating Role of Customer Satisfaction. European Journal of Marketing, pp.36.

${ }^{15}$ Heri Sudarsono, Bank dan Lembaga Kenangan Syariah, Cet ke-2, pp.126

${ }^{16}$ Hendi Suhendi, Fiqih Muamalah, Cet. Ke-1, pp.105
} 
sebagai kepercayaan dari suatu yang dapat dibayarkan dari harta itu bila utang tidak dibayar." ${ }^{\prime 7}$ Sedangkan menurut Ahmad Azhar Basyir "Rahn adalah menahan sesuatu barang sebagai tanggungan utang, atau menjadikan sesuatu benda bernilai menurut pandangan syara' sebagai tanggungan marbun bih, sehingga dengan adanya tanggungan utang itu seluruh atau sebagian utang dapat diterima." 18

Pegadaian menurut kitab Undang-Undang Hukum Perdata pasal 1150 yang berbunyi:

"Gadai adalah hak yang diperoleh seorang yang mempunyai piutang atas suatu barang bergerak. Barang tersebut diserahkan kepada orang yang berpiutang oleh seseorang yang mempunyai utang atau oleh orang lain atas nama orang yang mempunyai utang. Seseorang yang berutang tersebut memberikan kekuasaan kepada orang yang memberi utang untuk menggunakan barang bergerak yang telah diserahkan untuk melunasi utang apabila pihak yang berutang tidak dapat memenuhi kewajibannya pada saat jatuh tempo". ${ }^{19}$

Jadi, kesimpulanya bahwa "rahn adalah menahan barang jaminan pemilik, baik yang bersifat materi atau manfaat tertentu, sebagai jaminan atas pinjaman yang diterimanya. Barang yang diterima memperoleh jaminan untuk mengambil kembali seluruh atau sebagian hutangnya dari barang gadai tersebut apabila pihak yang mengadaikan tidak dapat membayar hutang tepat pada waktunaya."

\footnotetext{
${ }^{17}$ Muhammad Sholikul Hadi, Pegadaian Syariah, (Jakarta: Salemba Diniyah, 2003), pp.51

${ }^{18}$ Muhammad Sholikul Hadi, Pegadaian Syariah, pp.105

${ }^{19}$ Heri sudarsono, Bank dan Lembaga Keuangan Syariah, pp.156
} 


\section{At-Taqaddum}

Vol. 11 No. 2 (2019) pp 234-255

DOI: http://dx.doi.org/10.21580/at.v1li2.4632

\section{Faktor-Faktor Yang Mempengaruhi Loyalitas Konsumen Produk}

Kualitas produk adalah "the characteristic of a product or service that bear on its ability to satisfy stated or implied customer, yang artinya kualitas produk adalah karakteristik sebuah produk atau jasa yang memberikan kemampuan untuk mencukupi kebutuhan pelanggan." ${ }^{20}$

Kualitas produk adalah "keseluruhan kualitas atau keunggulan suatu produk atau jasa layanan berkaitan dengan apa yang diharapkan oleh pelanggan. Kualitas adalah totalitas fitur dan karakteristik yang memampukan produk memuaskan kebutuhan yang dinyatakan maupun tidak dinyatakan." 21

\section{Pelayanan}

Pelayanan pada dasarnya adalah "suatu tindakan atau cara melayani orang lain untuk memenuhi apa yang menjadi kebutuhan dan keinginannya. Maka pelayanan berkualitas adalah pelayanan yang harus sesuai dengan harapan yang diinginkan oleh setiap konsumen. Semakin tinggi tingkat kesesuaiannya, akan tercipta nilai kepuasan konsumen yang maksimal. Sehingga kualitas jasa harus dimulai dari kebutuhan pelanggan dan berakhir dengan kepuasan pelanggan serta persepsi positif terhadap kualitas jasa." 22

Kualitas produk adalah "suatu nilai dari produk atau jasa, dimana nilai produk atau jasa sesuai dengan apa yang diharapkan atau melebihi apa yang diharapkan sehingga produk atau jasa tersebut dapat memenuhi kebutuhan pemakainya." ${ }^{23}$ Kualitas yang baik dari suatu produk akan menghasilkan kepuasan konsumen. Suatu produk dapat dikatakan berkualitas apabila produk tersebut dapat memenuhi keinginan dan kebutuhan sesuai dengan yang diharapkan atau melebihi apa yang

\footnotetext{
${ }^{20}$ Kotler, Philip and Gary Armstrong. Principles of marketing 13e, (New Jersey: Pearson Education, Inc., 2010). pp. 229

${ }^{21}$ Kotler, Philip. dan Keller, Kevin Lane, Manajemen Pemasaran. Jilid 1 dan 2, Edisi Ke 12, (Jakarta: PT. Indeks, 2007), hlm. 173

${ }^{22}$ Kotler, Philip dan Gary Amstrong. 2000. Prinsip-Prinsip Pemasaran. Jakarta: Erlangga.

${ }^{23}$ Kotler, Philip dan Gary Amstrong. 2000. Prinsip-Prinsip Pemasaran. Jakarta: Erlangga.
} 
diinginkan konsumen. Menurut David" "untuk menentukan kualitas barang dapat melalui 8 dimensi yaitu: (a) performance; (b) features; (c) reliability; (d) conformance; (e) durability; (f) service ability; (g) aesthetics; dan (b) fit and finish."

Parasuraman ${ }^{25}$ mengidentifikasi 5 dimensi pokok yang berkaitan dengan kualitas jasa antara lain:

1) "Bukti langsung (tangibles), meliputi fasilitas fisik, perlengkapan, pegawai dan sarana komunikasi."

2) "Keandalan (reliability), yakni kemampuan memberikan pelayanan yang dijanjikan dengan segera, akurat dan memuaskan."

3) "Daya tanggap (responsiveness) yaitu kemampuan para staf untuk membantu para pelanggan dan memberikan pelayanan dengan tanggap."

4) "Jaminan (assurance) mencakup pengetahuan, kemampuan, kesopanan dan sifat dapat dipercaya yang dimiliki para staf, bebas dari bahaya, risiko dan keragu-raguan."

5) "Empati (empathy) meliputi kemudahan dalam melakukan hubungan komunikasi yang baik, perhatian pribadi dan memahami kebutuhan para pelanggan."

Selain melalui kualitas dan diperkuat dengan periklanan, loyalitas merek juga dapat dikembangkan melalui promosi. "Promosi merupakan aktivitas pemasaran yang berusaha menyebarkan informasi, mempengaruhi/membujuk, dan mengingatkan pasar sasaran atas perusahaan dan produknya agar bersedia menerima, membeli dan loyal pada produk yang ditawarkan perusahaan yang bersangkutan." ${ }^{26}$ Beberapa

\footnotetext{
${ }^{24}$ Umar Husein. 2000. Riset Pemasaran dan Perilaku Konsumen. Jakarta: PT. Gramedia Pustaka Utama.

25Parasuraman A, Zeithaml V and Berry L.L.,1988, "SERVQUAL: A Multi Item Scale for

Measuring Consumer Perceptions of Quality”, Journal of Retailing, Spring, p.12-38.

${ }^{26}$ Tjiptono, Fandy, 2000, “Manajemen Jasa”. Andi Offset, Yogyakarta
} 


\section{At-Taqaddum}

Vol. 11 No. 2 (2019) pp 234-255

DOI: http://dx.doi.org/10.21580/at.v1li2.4632

jenis promosi yang sering disebut sebagai bauran promosi menurut Swastha ${ }^{27}$ adalah: "(a) periklanan; (b) promosi penjualan; (c) personal selling; dan (d) public relation. Secara lebih sederhana, Shimp ${ }^{28}$, menggolongkan tujuan iklan, yaitu: "(a) informing (memberi informasi); (b) persuasioning (mempersuasi/membujuk); (c) reminding (mengingatkan); (d) adding value (memberi nilai tambah) dan (e) assisting (mendampingi) upaya-upaya lain dari perusahaan."

Selain itu menurut Mardalis" ${ }^{29}$ "terdapat juga faktor-faktor lainnya yang mempengaruhi loyalitas pelanggan, yaitu Kepuasan Pelanggan, Kualitas Jasa, dan Citra. Kepuasan pelanggan sebagai perasaan suka atau tidak seseorang terhadap suatu produk setelah ia membandingkan prestasi produk tersebut dengan harapannya. Kepuasan pelanggan sebagai tanggapan yang positif pada evaluasi terhadap pengalaman dalam menggunakan suatu produk atau jasa."

\section{Kepuasan Pelanggan}

Kotler dalam Setiawan ${ }^{30}$ mengemukakan bahwa "kepuasan pelanggan adalah perasaan senang atau kecewa seseorang yang muncul setelah membandingkan antara kinerja/hasil produk yang dipikirkan terhadap kinerja atau hasil produk yang diharapkan. Jika kinerja di bawah harapan, maka pelanggan merasa tidak puas. Sebaliknya jika memenuhi harapan bahkan lebih, maka pelanggan puas atau amat senang."

"Faktor utama penentu kepuasan pelanggan adalah persepsi pelanggan terhadap kualitas jasa. Sehingga persepsi pelanggan terhadap produk atau

\footnotetext{
${ }^{27}$ Swastha, Basu, 1999, "Loyalitas Pelanggan: sebuah Kajian Konseptual Sebagai Panduan bagi Peneliti”, Jurnal Ekonomi dan Bisnis Indonesia, Vol.14 no.3: 73-88, Yogyakarta, Universitas Gadjah Mada ${ }^{28}$ Shimp, Terence A. 2000. Periklanan Promosi. Jakarta: Penerbit Erlangga ${ }^{29}$ Mardalis, Ahmad, 2005, "Meraih Loyalitas Pelanggan", Benefit: Jurnal Manajemen dan Bisnis, Vol.9 no.2: 111-119, FE UMS, Surakarta

${ }^{30}$ Setiawan, Supriadi, 2011,'Loyalitas Pelanggan Jasa", Penerbit IPB Press, Bogor
} 
jasa tersebut akan berpengaruh terhadap tingkat kepentingan pelanggan, kepuasan pelanggan dan nilai." 31

\section{Loyalitas Pelanggan}

"Istilah loyalitas sudah sering didengar, seperti emosi dan kepuasan, loyalitas merupakan konsep lain yang nampak mudah dibicarakan dalam konteks sehari-hari, tetapi menjadi lebih sulit ketika dianalisis maknanya. Tidak banyak literatur yang mengemukakan definisi tentang loyalitas." 32 "Loyalitas dapat dipahami sebagai sebuah konsep yang menekankan pada runtutan pembelian seperti dikutip Mardalis." ${ }^{" 33}$ Loyalitas konsumen adalah "komitmen untuk bertahan secara mendalam dengan melakukan pembelian ulang atau berlangganan kembali dengan produk atau jasa terpilih secara konsisten di masa yang akan datang." ${ }^{34}$

\section{Hipotesis}

"Hipotesis yang diajukan dalam penelitian ini adalah: (a) kualitas produk berpengaruh positif dan signifikan terhadap loyalitas konsumen; (b) kualitas pelayanan berpengaruh positif dan signifikan terhadap loyalitas konsumen; (c) kepuasan pelanggan kualitas berpengaruh positif dan signifikan terhadap loyalitas konsumen; (d) kualitas produk, kualitas pelayanan, dan kepuasan pelanggan secara serentak berpengaruh signifikan terhadap loyalitas konsumen."

\footnotetext{
31Ziethaml, Valerie A., Leonard L. Berry, and A. Parasuraman, 1996,’The Behavioral Consequences of Service Quality", Journal of Marketing, Vol.60 pp.31-46

${ }^{32}$ Mardalis, A, Meraih Loyalitas Pelanggan, (Jakarta : Balai Pustaka, 2005), 112

${ }^{33}$ Mardalis,A, Meraib Loyalitas Pelanggan, (Jakarta : Balai Pustaka, 2005), 112

${ }^{34}$ Bowen, Shiang-Lih Chen, 2001, The relationship between customer loyalty and customer satisfaction, International Journal of Contemporary Hospitality Management, Vol. 13 Iss: 5, pp. 214
} 


\section{At-Taqaddum}

Vol. 11 No. 2 (2019) pp 234-255

DOI: http://dx.doi.org/10.21580/at.v11i2.4632

\section{Metodologi}

Jenis penelitian yang digunakan dalam penelitian ini adalah penelitian kuantitatif $^{35}$ dengan menggunakan Analisis Jalur. ${ }^{36}$ Sampel ini dipilih dengan menggunakan Random Sampling yaitu dengan memilih secara acak sampel dari populasi. ${ }^{37}$ Terdapat 175 responden. Teknik pengumpulan data dalam penelitian ini menggunakan angket. ${ }^{38}$

\section{Hasil}

Jumlah sampel yang dipilih dalam penelitian ini sebesar 300 orang. Dari total kuesioner yang disebar tersebut, jumlah yang kembali adalah sebanyak 172 set kuesioner. Hal ini berarti bahwa response rate (tingkat pengembalian) kuesioner oleh responden sebesar 100\%. Hal tersebut mengindikasikan bahwa respon responden untuk mengisi kuesioner penelitian, dan mengembalikannya adalah tinggi. Dalam hal ini peneliti menyebar sejumlah 172 kuesioner sendiri untuk memastikan pengembalian kuesioner oleh responden.

Dalam pengumpulan data primer ini, peneliti tidak menemukan adanya kuesioner yang rusak, baik karena jawaban responden yang tidak lengkap atau karena responden mengisi lebih dari satu jawaban untuk pertanyaan yang sama. Oleh karena itu, seluruh kuesioner yang terkumpul dapat dianalisis secara statistik. Hasil analisa karakteristik responden berdasarkan usia, jenis kelamin, pendidikan terakhir dan pekerjaan ditunjukkan pada tabel-tabel berikut:

\footnotetext{
${ }^{35}$ Sugiyono, Metode Penelitian Kuantitatif Kualitatif dan R \& D, (Bandung, Alfabeta, 2015), hlm. 3

${ }^{36}$ Imam Ghozali, Aplikasi Analisis Multivariate dengan Program SPSS, Edisi Ketujuh, (Semarang: Badan Penerbit Universitas Diponegoro, 2013), hlm. 249.

${ }^{37}$ Sugiyono, Metode Penelitian Kuantitatif Kualitatif dan R \& D, hlm. 123

${ }^{38}$ Sugiyono, Metode Penelitian Kuantitatif Kualitatif dan R \& D, hlm. 308
} 
Tabel 1.1. Deskripsi Responden Berdasarkan Usia

\begin{tabular}{ccc}
\hline Usia & Frekuensi & Persentase \\
\hline $17-21$ tahun & 30 & $17,5 \%$ \\
\hline $22-26$ tahun & 49 & $28 \%$ \\
\hline $27-31$ tahun & 39 & $22,5 \%$ \\
\hline $32-36$ tahun & 33 & $19,5 \%$ \\
\hline $37-42$ tahun & 21 & $12,5 \%$ \\
\hline
\end{tabular}

Dari Tabel 1.1 menunjukkan bahwa persentase responden yang terkumpul berdasarkan usianya adalah responden dengan usia $17-21$ tahun sebesar 30 responden $(17,5 \%)$, usia 22 - 26 tahun sebesar 49 responden (28\%), usia 27 - 31 tahun sebesar 39 responden $(22,5 \%)$, usia 32 - 36 tahun sebesar 33 responden (19,5\%) dan usia 37 - 42 tahun sebesar 21 responden $(12,5 \%)$.

Tabel 1.2. Deskripsi Responden Berdasarkan Jenis Kelamin

\begin{tabular}{|l|c|c|}
\hline Jenis Kelamin & Frekuensi & Persentase \\
\hline Pria & 90 & $52 \%$ \\
\hline Wanita & 82 & $48 \%$ \\
\hline
\end{tabular}

Sedangkan untuk Tabel 1.2 menunjukkan bahwa persentase responden yang terkumpul berdasarkan jenis kelaminnya adalah sebesar 52\% atau 90 responden berjenis kelamin pria dan $48 \%$ atau 82 responden berjenis kelamin wanita.

Tabel 1.3. Deskripsi Responden Berdasarkan Pendidikan Terakhir

\begin{tabular}{|c|c|c|}
\hline Pendidikan & Frekuensi & Persentase \\
\hline SLTA & 45 & $26,5 \%$ \\
\hline D3 & 38 & $22 \%$ \\
\hline
\end{tabular}




\section{At-Taqaddum}

Vol. 11 No. 2 (2019) pp 234-255

DOI: http://dx.doi.org/10.21580/at.v1li2.4632

\begin{tabular}{|c|c|c|}
\hline S1 & 83 & $47,5 \%$ \\
\hline S2 & 6 & $4 \%$ \\
\hline
\end{tabular}

Di sisi lain untuk jumlah responden yang dikelompokkan berdasarkan tingkat pendidikan terakhir pada Tabel 1.3 adalah responden dengan tingkat pendidikan SLTA sebanyak 45 responden (26,5\%), yang berpendidikan D3 sebanyak 38 responden (22\%), berpendidikan S1 sebanyak 83 responden (47,5\%), diikuti yang berpendidikan S2 sebanyak 6 responden (4\%).

Tabel 1.4. Deskripsi Responden Berdasarkan Pekerjaan

\begin{tabular}{|l|l|l|}
\hline \multicolumn{1}{|c|}{ Pekerjaan } & Frekuensi & Persentase \\
\hline Karyawan Swasta & 68 & $40 \%$ \\
\hline Mahasiswa & 23 & $13,5 \%$ \\
\hline PNS & 38 & $22 \%$ \\
\hline Wiraswasta & 43 & $24,5 \%$ \\
\hline
\end{tabular}

Tabel 1.4 menunjukkan bahwa sebagian besar responden bekerja sebagai karyawan swasta sebanyak 68 responden $(40 \%)$, sedangkan responden yang lain masih sebagai mahasiswa sebanyak 23 responden (13,5\%), bekerja sebagai PNS sebanyak 38 responden (22\%) dan sebagai wiraswasta sebanyak 43 responden $(24,5 \%)$.

Pada analisis jalur digunakan model estimasi sebagai berikut:

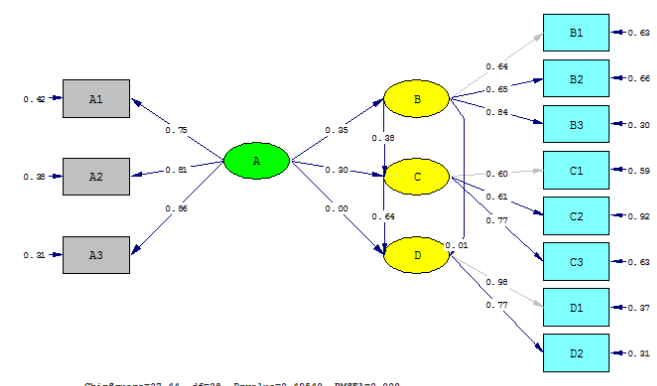

Gambar 1.1 Model Estimasi dari Lisrel 
Sebelum melakukan teknik pengujian hipotesis, langkah yang pertama adalah menilai kesesuaian goodness-of-fit. Untuk mengujinya akan digunakan Structural Equation Modeling (SEM) dengan bantuan program LISREL 8.5. Evaluasi nilai goodness-of-fit dari model penelitian yang diajukan dapat dilihat pada Tabel 1.5 berikut ini:

Tabel 1.5. Hasil Goodness-of-Fit Model

\begin{tabular}{|l|l|c|c|}
\hline \multicolumn{1}{|c|}{ Goodness-of-fit Indices } & Cut-off Value & Hasil & Evaluasi Model \\
\hline Chi-Square $\left(\mathrm{X}^{2}\right)$ & $<2 \mathrm{kali} \mathrm{df}=76$ & 37.44 & Fit \\
\hline $\begin{array}{l}\text { Significance Probability } \\
\text { (P) }\end{array}$ & $>0,05$ & 0.49540 & Fit \\
\hline RMSEA & $<0,08$ & 0.000 & Fit \\
\hline GFI & $>0.9$ & 0.96 & Fit \\
\hline
\end{tabular}

Pada tabel 1.5 dapat dilihat bahwa chi-square yang bernilai 37.44 dengan degree of freedom 76 adalah signifikan secara statistik pada level signifikansi 0,000. Probabilitas sebesar 0.49540 lebih besar dari 0,05 hal ini merupakan indikasi yang baik. Nilai GFI sebesar 0.96 merupakan indikasi yang sangat baik karena lebih besar dari 0.9. Nilai RMSEA sebesar 0.000 merupakan indikasi yang baik karena kurang dari 0.08. Sementara dari indeks incremental fit measures didapat nilai AGFI sebesar 0,767 merupakan indikasi yang buruk. Nilai TLI sebesar 0,837 merupakan indikasi yang marginal. Nilai CFI sebesar 0,855 merupakan indikasi yang marginal. Sebagai tambahan dari indeks parsimony fit measures didapat nilai CMIN/df sebesar 2,179 merupakan indikasi yang baik karena mempunyai nilai kurang dari 3.

Dari keseluruhan pengukuran goodness of fit tersebut di atas mengindikasikan bahwa model yang diajukan dalam penelitian ini belum dapat diterima. Karena model yang diajukan dalam penelitian ini belum dapat diterima maka peneliti mempertimbangkan untuk melakukan modifikasi model untuk membentuk model alternatif yang mempunyai goodness of fit yang lebih baik. 


\section{At-Taqaddum}

Vol. 11 No. 2 (2019) pp 234-255

DOI: http://dx.doi.org/10.21580/at.v1li2.4632

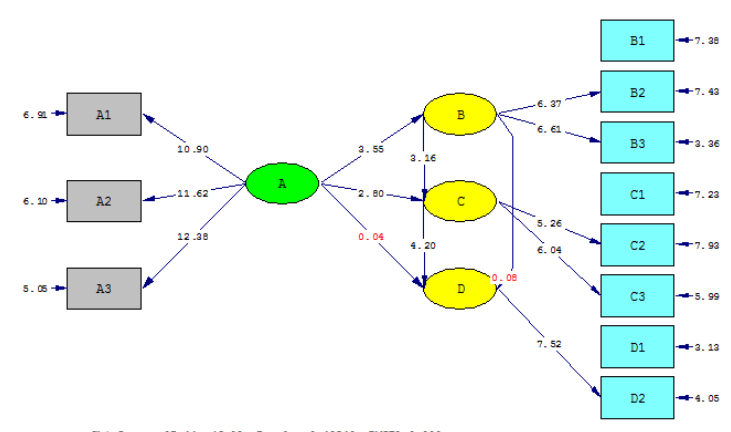

Gambar 1.2. Output t-value Lisrel

Dari hasil penghitungan t-value dengan menggunakan Lisrel dapat dipersingkat penjelasan seperti pada tabel berikut:

Tabel 1.6. Hasil Penghitungan Pengaruh

\begin{tabular}{cccccc}
\hline Variabel & Koef. Korelasi & \multicolumn{5}{c}{ Dampak (Effect) } \\
\cline { 3 - 6 } Laten & & TE & DE & IE & S \\
\hline A - B & 0.35 & 0.35 & 0.35 & - & 0 \\
\hline A - C & 0.43 & 0.43 & 0.30 & 0.13 & 0 \\
\hline A - D & 0.28 & 0.28 & 0.00 & 0.28 & 0 \\
\hline B - C & 0.48 & 0.37 & 0.37 & - & 0.11 \\
\hline B - D & 0.32 & 0.25 & 0.01 & 0.24 & 0.07 \\
\hline C - D & 0.65 & 0.64 & 0.64 & - & 0.01 \\
\hline
\end{tabular}

Keterangan:

A : Kualitas Produk

B : Pelayanan

C : Kepuasan pelanggan

D : Loyalitas pelanggan

Hasil pengujian menunjukkan bahwa kualitas produk mempengaruhi pelayanan sebesar 0.35, mempengaruhi kepuasan pelanggan sebesar 0.43. Kualitas barang mempengaruhi loyalitas 
pelanggan sebesar 0.28 . Pelayanan mempengaruhi kepuasan pelanggan sebesar 0.48 \& mempengaruhi loyalitas pelanggan sebesar 0.32 . Kepuasan pelanggan mempengaruhi loyalitas pelanggan sebesar 0.65 .

Dari keterangan sebelumnya dapat dijelaskan bahwa variabel yang mendapat pengaruh paling besar dari variabel kualitas produk adalah variabel kepuasan pelanggan. Hal ini terlihat dari nilai total effect terbesar terjadi dari variabel kualitas produk ke variabel kepuasan pelanggan. Selain itu juga terlihat dari output t-values terbesar dari variabel kualitas produk ke variabel kepuasan pelanggan, yaitu 2.80. Hal ini sesuai dengan landasan teori karena pada dasarnya kualitas produk menciptakan gejala kepuasan pelanggan yaitu kualitas produk yang berkualitas baik mampu secara nyata mampu memenuhi kepuasan pelanggan dalam membeli. Dari tabel di atas juga terlihat bahwa kualitas produk memberi pengaruh yang besar pada pelayanan yaitu kualitas pelayanan terhadap konsumen. Hal ini dibuktikan dengan pengaruh kualitas produk terhadap pelayanan yang relativ besar yaitu dengan total efect 0.35 dan output t-value sebesar 3.55.

Variabel yang mendapatkan pengaruh paling kecil dari varaiabel kualitas produk adalah variabel loyalitas pelanggan. Hal ini terlihat dari nilai total effect terkecil terjadi dari variabel kualitas produk ke variabel loyalitas pelangan. Selain itu juga terlihat dari output t-values terkecil dari kualitas produk ke loyalitas pelanggan, yaitu 0.04 . Hal ini sesuai dengan landasaran teori karena kualitas produk cenderung memberi pengaruh negativ terhadap loyalitas pelanggan karena yang ditawarkan kualitas produk adalah murni produk tidak sampai pada segi psikologis pelanggan.

\section{Kesimpulan}

Berdasarkan hasil penelitian yang penulis lakukan tentang "pengaruh kualitas produk, kualitas pelayanan, kepuasan pelanggan terhadap loyalitas pelanggan Pegadaian syariah Kusumanegara 


\section{At-Taqaddum}

Vol. 11 No. 2 (2019) pp 234-255

DOI: http://dx.doi.org/10.21580/at.v1li2.4632

Yogyakarta dengan menggunakan tekinik path analysis" Penulis mengambil simpulan sebagai berikut :

"Hasil pengujian mengindikasikan hasil yang mendukung hipotesis $(\mathrm{R}=0.35)$ maka menunjukkan bahwa hipotesis 1 diterima pada tingkat signifikan $\alpha=0,001$ akan tetapi hubungan ini relatif kecil. Hasil ini menunjukkan bahwa Kualitas Produk merupakan variabel yang dianggap kurang penting dalam membentuk Pelayanan."

"Hasil pengujian mengindikasikan hasil yang mendukung hipotesis $(\mathrm{R}=0.43)$, maka menunjukkan bahwa hipotesis 2 diterima pada tingkat signifikansi $\alpha=0,01$. Hal ini menunjukkan bahwa kualitas produk merupakan variabel yang dianggap signifikan dalam membentuk kepuasan pelanggan."

"Hasil pengujian mengindikasikan hasil yang mendukung hipotesis $(\mathrm{R}=0.28)$, maka menunjukkan bahwa hipotesis 3 diterima pada tingkat signifikansi $\alpha=0,05$. Hasil ini menunjukkan bahwa kualitas barang merupakan variabel yang dianggap tidak terlalu esensial dalam membentuk loyalitas pelanggan."

"Hasil pengujian mengindikasikan hasil yang mendukung hipotesis $(\mathrm{R}=0.48)$, maka menunjukkan bahwa hipotesis 4 diterima pada tingkat signifikansi $\alpha=0,05$. Hasil ini menunjukkan bahwa pelayanan merupakan variabel yang dianggap penting dalam membentuk kepuasan pelanggan."

"Hasil pengujian mengindikasikan hasil yang mendukung hipotesis $(\mathrm{R}=0.32)$, maka menunjukkan bahwa hipotesis 5 diterima pada tingkat signifikansi $\alpha=0,05$. Hasil ini menunjukkan bahwa pelayanan merupakan variabel yang dianggap tidak terlalu penting dalam membentuk loyalitas pelanggan."

"Hasil pengujian mengindikasikan hasil yang mendukung hipotesis $(\mathrm{R}=0.65)$, maka menunjukkan bahwa hipotesis 6 diterima pada tingkat signifikansi $\alpha=0,001$. Hasil ini menunjukkan bahwa kepuasan pelanggan merupakan variabel yang dianggap sangat penting dalam membentuk loyalitas pelanggan.” 


\section{Referensi}

Bowen, Shiang-Lih Chen, 2001, The relationship between customer loyalty and customer satisfaction, International Journal of Contemporary Hospitality Management, Vol. 13 Iss: 5, pp.214

Caruana, A., 2002, Service Loyalty The Effects of Service Quality and The Mediating Role of Customer Satisfaction. European Journal of Marketing, 36.

Dick, A.S dan Basu, K., 1994, "Customer Loyalty: Toward an Integrated Conceptual Framework", Journal of The Academy Marketing Science, Vol.22, p.99-113.

Fryman, Mark A., Quality and Process Improvement, Delmar Thomson Learning, 2002

Ghozali, Imam, Aplikasi Analisis Multivariate dengan Program SPSS, Edisi Ketujuh, (Semarang: Badan Penerbit Universitas Diponegoro, 2013

Hadi, Muhammad Sholikul, Pegadaian Syariah, Jakarta: Salemba Diniyah, 2003

Husein, Umar, Riset Pemasaran dan Perilaku Konsumen, Jakarta: PT. Gramedia Pustaka Utama, 2000.

Kartajaya, Hermawan, Strategic Marketing Plan, Jakarta: PT. Gramedia. Pustaka Utama, 2004

Kotler, Philip \& Amstrong, Gary, Prinsip-Prinsip Pemasaran, Jakarta: Erlangga, 2000.

Kotler, Philip \& Armstrong, Gary, Principles of marketing 13e, New Jersey: Pearson Education, Inc., 2010

Kotler, Philip. dan Keller, Kevin Lane, Manajemen Pemasaran. Jilid 1 dan 2, Edisi Ke 12, Jakarta: PT. Indeks, 2007 


\section{At-Taqaddum}

Vol. 11 No. 2 (2019) pp 234-255

DOI: http://dx.doi.org/10.21580/at.v11i2.4632

Krajewski, Lee J. \& Ritzman, Larry P., Operations Management: Strategy and Analysis, Fourth Edition, Addison Wesly Publishing Co., 1996

Lupiyoadi, Rambat, Manajemen Pemasaran Jasa, Teori dan Praktek, Edisi Pertama, Jakarta: Salemba Empat, 2001

Mardalis, A, Meraih Loyalitas Pelanggan, Jakarta: Balai Pustaka, 2005

Mardalis, Ahmad, 2005, "Meraih Loyalitas Pelanggan”, Benefit: Jurnal Manajemen dan Bisnis, Vol.9 no.2: 111-119, FE UMS, Surakarta

Muhamad (ed.), Bank Syariah Analisis Kekuatan, Peluang, Kelemahandan Ancaman, Yogyakarta: Ekonisa, 2006

Parasuraman A, Zeithaml V and Berry L.L.,1988, "SERVQUAL: A Multi Item Scale for Measuring Consumer Perceptions of Quality", Journal of Retailing, Spring, p.12-38.

Setiawan, Supriadi, "Loyalitas Pelanggan Jasa", Penerbit IPB Press, Bogor, 2011

Shimp, Terence A., Periklanan Promosi, Jakarta: Penerbit Erlangga, 2000

Siregar, S.P. 2004. Analisis Kepuasan Para Anggota Terbadap Program Loyalitas Astraworld. Tesis Fakultas Ekonomi Universitas Indonesia, tidak diterbitkan.

Sudarsono, Heri, Bank dan Lembaga Kenangan Syari'ah, Cet. III, Yogyakarta: Ekonomi, 2005

Sugiyono, Metode Penelitian Kuantitatif Kualitatif dan $\mathrm{R} \& \mathrm{D}$, Bandung, Alfabeta, 2015

Sunendi, Hendi, BMT dan Bank Islam, Bandung: Pustaka Bani Quraisy, 2004

Swastha, Basu \& Handoko, Hani, Manajemen Pemasaran, Analisa Perilaku Konsumen, Yogyakarta: BPFE, 2000 
Swastha, Basu, "Loyalitas Pelanggan: sebuah Kajian Konseptual Sebagai Panduan bagi Peneliti", Jurnal Ekonomi dan Bisnis Indonesia, Vol.14 no.3: 73-88, Yogyakarta, Universitas Gadjah Mada, 1999

Tjiptono, Fandy, "Manajemen Jasa”, Andi Offset, Yogyakarta, 2000

Tjiptono, Fandy, Strategi Pemasaran Edisi ketiga, Yogyakarta: Andi, 2008

Ziethaml, Valerie A., Leonard L. Berry, and A. Parasuraman, 1996, "The Behavioral Consequences of Service Quality", Journal of Marketing, Vol.60 pp.31-46 